\title{
Työturvallisuuden parantaminen maatalouden tuotantorakentamisessa
}

\author{
Kim O. Kaustell ${ }^{1)}$, Maarit Hellstedt ${ }^{2}$, Tapani Kivinen $^{3)}$ \\ ${ }^{1)}$ MTT Taloustutkimus, Latokartanonkaari 9,00790 Helsinki, kim.kaustell@mtt.fi \\ ${ }^{2)}$ MTT Kotieläintuotannon tutkimus, Kampusranta 9 C, 60320 Seinäjoki, maarit.hellstedt@mtt.fi \\ ${ }^{3)}$ MTT Kotieläintuotannon tutkimus, Vakolantie 55, 03400 Vihti, tapani.kivinen@mtt.fi
}

\section{Tiivistelmä}

Maatilat ovat kasvaneet Suomen EU-jäsenyyden aikana huomattavasti. Kasvu on merkinnyt isoja investointeja uusiin tuotantorakennuksiin. Rakentamisessa on siirrytty pienimuotoisista omaa puutavaraa ja omaa työpanosta sisältäneistä hankkeista suuriin hallimaisiin projekteihin. Suhteellisesti vaarallisimmat työtehtävät suurimmassa osassa maatalousyrityksiä löytyvät tutkimusten mukaan maatilatalouden "muista töistä” sekä rakennus- ja metsätöistä. Tämän, Maatalousyrittäjien eläkelaitoksen rahoittaman hankkeen tavoitteena oli parantaa maatilojen uudis- ja korjausrakentamisen työturvallisuuden tasoa kokoamalla maatilalla tapahtuvan rakentamisen turvallisuutta koskevaa tietoa ja kehittämällä vallitsevia käytäntöjä parempia toimintatapoja. hanke koostuu kirjallisuus- ja tilasto-osioista sekä viljelijä- ja suunnittelijahaastatteluista.

Kirjallisuusosiossa on etsitty viimeisimmistä kotimaisista rakennustyöturvallisuustutkimuksista sekä ulkomaisista maatalousrakentamisen työturvallisuuteen liittyvistä tutkimuksista toimintatapoja/hyviä käytäntöjä ja arvioitu niiden soveltuvuutta meidän olosuhteisiimme.

Tilasto-osiossa on verrattu Maatalousyrittäjien eläkelaitoksen MATA-tapaturmatietokannasta vuosilta 2005...2008 maatalousyrittäjille rakennustöissä sattuneita tapaturmia Tapaturmavakuutuslaitosten liiton tapaturmarekisteristä saataviin rakennustyöntekijöiden tapaturmiin. MATA-tietokannan mukaan eniten tapaturmia sattui tuotantorakennusten korjaus- ja kunnossapitotöissä (39,5 \%), peruskorjaus- ja laajennustöissä (18,6 \%) sekä uudisrakentamisessa (26,5 \%). Nämä tapaturmat aiheuttivat maatalousyrittäjille yhteensä 46505 työkyvyttömyyspäivää. Keskimääräinen tapaturman aiheuttama työkyvyttömyysaika oli 38,6 päivää. Tyypillisin ajankohta tapaturmalle oli heinäkuu.

Viljelijähaastatteluilla selvitettiin tilojen rakennustyömaan työturvallisuustoimenpiteet, mahdolliset sattuneet tapaturmat ja niiden tyypit, läheltä piti -tilanteet ja tapaturmaan johtaneet taustatekijät, rakennustyön turvallisuuspuutteet sekä tapaturmien välittömät ja välilliset, kuten rakennusprojektin valmistumisen viivästymisestä aiheutuneet kustannukset. Suunnittelijahaastatteluilla selvitettiin, miten työsuojelunäkökohdat otetaan huomioon maatilarakennussuunnittelussa ja -neuvonnassa, ja miten asia suunnittelijoiden kokemuksen mukaan tulisi huomioida, jotta työturvallisuustilanne saataisiin paranemaan.

Haastattelujen perusteella viljelijät tunsivat huonosti työsuojeluvelvoitteensa. Tilannetta heikensi vielä se, että työmaalla vastaavan työjohtajan tehtäviä hoidettiin pääsääntöisesti nimellisesti. Suunnittelijat tunsivat työsuojelulainsäädännön paremmin, mutta sen jalkautus työmaille ei toiminut, koska he eivät pääsääntöisesti osallistuneet varsinaiseen rakennushankkeen toteutukseen.

\section{Asiasanat}

Rakentaminen, turvallisuus, tuotantorakennus, maatalous 


\section{Johdanto}

Suomen maataloudessa on EU-jäsenyyden aikana 15 vuodessa tapahtunut merkittävä rakennemuutos. Maatilojen lukumäärä on supistunut ja jäljelle jääneet maatilat ovat kasvaneet huomattavasti. Kasvu on merkinnyt myös isoja investointeja uusiin tuotantorakennuksiin. Tämä kehitys näyttää edelleen jatkuvan. Rakentamisessa on siirrytty pienimuotoisista omaa puutavaraa ja omaa työpanosta sisältäneistä hankkeista suuriin hallimaisiin projekteihin, joissa elementtitekniikka ja ammattimainen rakentamisen tarve ovat leimaa antavia. Maatalouden tuotantorakennusten osuus maamme rakentamisesta on noin $10 \%$ kaikista rakennuskuutioista. Rakennusinvestointien arvo on vuositasolla n. 350 miljoonaa euroa, mikä vastaa $5 \%$ rakennusklusterin euroista (MMM 2009). Kaikista hallimaisista tuotantorakennuksista maatalouden osuus on liki $40 \%$ (Tilastokeskus 2009).

Vuosittain maataloudessa toteutetaan noin 1500 rakennushanketta. Latvalan ja Pyykkösen (2009) mukaan viimeaikaisten navettahankkeiden keskimääräinen koko on 1400 m2 ja 7850 m3 ja kustannus keskimäärin $800000 €$. Rakentamiseen osallistuu arviolta 20 rakennusurakoitsijaa, 200 ammattiryhmää (kirvesmiesporukat) sekä 1300 hartiapankkirakentajaa (viljelijää). Viimemainittuun ryhmään kuuluvat myös maatiloilla toimivat lomittajat ja maatalousharjoittelijat, tilalle palkatut maataloustyöntekijät sekä ns. talkooväki, joilla harvoin on varsinaista perehdytystä rakennustöihin, työmaajärjestelyihin ja turvallisuuteen.

Vuoden 2003 alussa tuli voimaan uusi työturvallisuuslaki (Työturvallisuuslaki 2003), joka painottaa ennakoivaa työturvallisuutta. Lain perusteella annettiin kesäkuussa 2009 voimaan astunut Valtioneuvoston asetus rakennustyön turvallisuudesta (VnA 2009). Laki tähtää työpaikan oma-aloitteiseen turvallisuuden hallintaan osana tuloksellista ja yhteiskuntavastuullista johtamista. Asetus puolestaan täsmentää rakennushankkeen osapuolten työturvallisuuteen liittyviä vastuita.

Myös maatiloilla on aito halu työturvallisuuden parantamiseen. Ongelmana on tiedon sekä hyvien työsuojelusuunnitelma- ja toimintatapamallien puute. Myös maatalousyrittäjän tietämys hänen todellisesta työsuojeluvastuustaan rakennustyömaalla on puutteellinen. Yksittäisten työturvallisuutta edistävien ratkaisujen oheen tarvitaan siten tietoja ja taitoja rakennustyömaiden kokonaisvaltaisen turvallisuuden kehittämiseksi.

Tämän hankkeen tarkoituksena oli puuttua yhteen suomalaisen rakennustuotannon unohdetun sektorin, maatalouden talonrakennuksen rakentamisen, turvallisuustekijöihin. Haaste on ajankohtainen, koska uusien tuotantoyksiköiden koot kasvavat edelleen ja omatoimirakentaminen on edelleen yleistä alalle tulossa olevista uusista rakennusurakoitsijoista huolimatta. Hankkeen tavoitteena oli parantaa maatilojen uudis- ja korjausrakentamisen työturvallisuuden tasoa kokoamalla maatilalla tapahtuvan rakentamisen turvallisuutta koskevaa tietoa ja kehittämällä vallitsevia käytäntöjä parempia toimintatapoja.

\section{Aineisto ja menetelmät}

Hanke rajattiin koskemaan rakentamisprosessia talonrakennustyömaalla. Maatalouden erityispiirteenä mukaan tulee rakennustyömaan sijainti maatilan pihapiirissä ja siitä aiheutuvat turvallisuusriskit ja vaatimukset.

\section{Kirjallisuus- ja tilastoselvitys}

Kirjallisuusselvityksessä etsittiin koti- ja ulkomaisia maatalousrakentamisen työturvallisuuteen liittyviä tutkimuksia ja toimintatapoja/hyviä käytäntöjä ja arvioitiin niiden soveltuvuutta meidän olosuhteisiimme. Viimeisimmät kotimaiset rakennustyöturvallisuustutkimukset käytiin läpi ja etsittiin niistä hyviä malleja sovellettaviksi maatalousrakentamiseen. Kirjallisuusselvitykseen kuului myös maatiloilla tapahtuvaa rakentamista koskevan työturvallisuuslainsäädännön inventointi.

Tilastoselvityksen tavoitteena oli hankkia tietoa maatalouden talonrakennuksen työturvallisuuden nykytilasta, tyypillisistä tapaturmista, niiden syistä sekä kustannuksista. Tutkimuksessa käytettiin Maatalousyrittäjien eläkelaitoksen MATA-tapaturmatietokantaa. Tämä tietokanta sisältää maatalousyrittäjille sattuneet, korvatut tapaturmat. Melasta pyydetty aineisto kattoi rakennustöissä sattuneet, korvatut tapaturmat vuosilta 2005..2008. Lisäksi haluttiin arvioida, eroaako maatilarakentaminen muusta rakentamisesta työtapaturmien aiheuttajien ja muiden tekijöiden osalta. Vertailuaineistona käytettiin Tapaturmavakuutuslaitosten liiton tapaturmarekisteriä. Aineisto pyydettiin vastaavilta vuosilta kuin MATA-aineisto. 


\section{Suunnittelija- ja viljelijähaastattelut}

Hankkeessa tehtiin kaksi erillistä haastattelua. Maatalousrakennusten suunnittelijoilta kysyttiin webpohjaisella lomakkeella työturvallisuuteen liittyviä seikkoja. Haastatteluun vastasi 11 suunnittelijaa, joista 4 oli ProAgrian kokeneita suunnittelijoita. Seitsemän vastaajaa edusti omia yrityksiään, jotka ovat toimineet maatalouden rakennussuunnittelussa useita vuosia.

Viljelijähaastatteluihin saatiin 8 kohdetta., jotka pyrittiin valitsemaan siten, että ne laajasti edustivat eri tuotantorakennustyyppejä. Kohteina oli 2 emakkosikalaa, 2 lampolaa, 3 kanalaa ja 1 lypsykarjapihatto. Viljelijäkohteiden valinnassa pyrkimyksenä oli etsiä tiloja, joissa isännän ja isäntäperheen oman työn osuus olisi ollut mahdollisimman suuri. Viljelijöiltä kysyttiin rakentamisen työturvallisuuteen liittyviä kysymyksiä, joiden avulla arvioitiin, kuinka työturvallisuus oli tai olisi pitänyt ottaa huomioon toteutetussa rakennushankkeessa. Myös työturvallisuutta koskevien säännösten ja velvlitteiden tuntemusta selvitettiin.

\section{Tulokset ja tulosten tarkastelu}

\section{Työtapaturmat rakentamisessa}

Rakennustöissä sattuneet tapaturmat aiheuttivat maatalousyrittäjille tarkastellun neljän vuoden aikana yhteensä 46505 työkyvyttömyyspäivää. Keskimääräinen työkyvyttömyysaika oli 38,6 päivää. Vuonna 2008 Maatalousyrittäjien eläkelaitos korvasi 5520 työaikana sattunutta tapaturmaa. Yhteenlaskettu korvaussumma näistä oli 27,0 MEUR. Rakennustöissä sattuneiden tapaturmien osuus oli $6 \%$ eli noin 1,62 MEUR. Rakennushankkeen mahdollisesta viivästymisestä aiheutuneita kustannuksia ja muita välillisiä seurauksia on vaikea arvioida. Oinonen \& Aaltonen (2007) ovat arvioineet, että epäsuorat, välilliset kustannukset ovat yleensä välittömiä kustannuksia paljon suurempia.

Vuosina 2005...2008 maatalousyrittäjille sattui rakennustöissä yhteensä 1205 rekisteröityä (korvattua) tapaturmaa. Tämä on vuosittain 5-6 \% kaikista maatalousyrittäjien tapaturmista. Eniten tapaturmia sattui tuotantorakennusten korjaus- ja kunnossapitotöissä (39,5 \%), peruskorjaus- ja laajennustöissä (18,6 \%) sekä uudisrakentami-sessa (26,5 \%). Suurin osa (92 \%) rakennustöiden tapaturmista sattui miehille. Keski-ikä oli 47,7 vuotta, mutta haitari ulottui $17 . .83$ vuoteen asti. Tyypillisin ajankohta tapaturmalle oli heinäkuu.

Vahingoittumistapa oli useimmiten iskeytyminen putoamalla johonkin/jotakin vasten. Näitä oli 26 $\%$ kaikista rakennustyön tapaturmista. Muita usein esiintyviä vahingoittumistapoja olivat kontakti johonkin leikkaavaan esineeseen kuten veitseen tai muuhun viiltävään terään (11,5 \%), sekä tuki- ja liikuntaelimiin kohdistunut fyysinen kuormitus (10,8 \%). Maatalousyrittäjille rakennustyömailla sattuneiden tapaturmien tyypilliset aiheuttajat erosivat kaikkien rakennustyömaiden palkkatyövoiman tyypillisistä tapaturman aiheuttajista. Rakennustyöntekijöille tapaturmia aiheuttivat eniten materiaalit, esineet ja sirpaleet (35\%), sekä kulkuväylät, alustat maat, ovet, seinät yms. (18\%), kun maatalousyrittäjillä tyypillisin aiheuttaja olivat rakennustelineet ja tikkaat (Taulukko 1).

Taulukko 1. Rakentamistapaturmien aiheuttajien jakaumat viljelijöille (MATA) ja rakennustyöntekijöille (TVL)

\begin{tabular}{|l|c|c|}
\hline Aiheuttaja & $\begin{array}{c}\text { MATA } \\
\text { [\%] }\end{array}$ & $\begin{array}{c}\text { TVL } \\
\text { [\%] }\end{array}$ \\
\hline Rakennustelineet ja irtotikkaat & $\mathbf{1 8 , 2}$ & 3,4 \\
\hline $\begin{array}{l}\text { Maaston (jään) epätasaisuus, liukkaus, pettävyys, } \\
\text { maamassat }\end{array}$ & 16,6 & 18,0 \\
\hline $\begin{array}{l}\text { Aineet, tavarat, tarvikkeet, välineet, ulkoinen työympäristö, } \\
\text { aidat, kuormat }\end{array}$ & 13,2 & $\mathbf{3 4 , 7}$ \\
\hline $\begin{array}{l}\text { Sirkkelit, sahat, työstö- ja katkaisukoneet, pilkkomiskoneet, } \\
\text { hakkurit, käsikäyttöiset pora- ja hiomakoneet }\end{array}$ & 10,0 & 3,7 \\
\hline Käsityökalut & 9,2 & 8,6 \\
\hline
\end{tabular}




\section{Työturvallisuuteen liittyvät vastuut ja säännökset}

Toimivan työturvallisuuden perusedellytyksenä ovat selkeät työturvallisuusvastuut. Vastuualueet, tehtävät ja velvollisuudet tulee määritellä ja jokaisen tulee tuntea omat vastuunsa ja tehtävänsä. Työturvallisuusvastuun jakamisessa tulee huolehtia siitä, että vastuut kattavat kaikki tehtävät ja toiminnot, jolloin mitään epäselviä vastuualueita ei ole olemassa. Työturvallisuusvastuiden osalta on syytä muistaa, että lainsäädäntö asettaa jokaiselle työntekijälle työturvallisuusvastuuta ja -tehtäviä. Mäkelä (2006) on laatinut talonrakentamisen yleisiä turvallisuuskäytäntöjä käsitekartan (kuva 1), jossa esitetään ne osa-alueet, joiden toteutus vaatii suunnittelua.

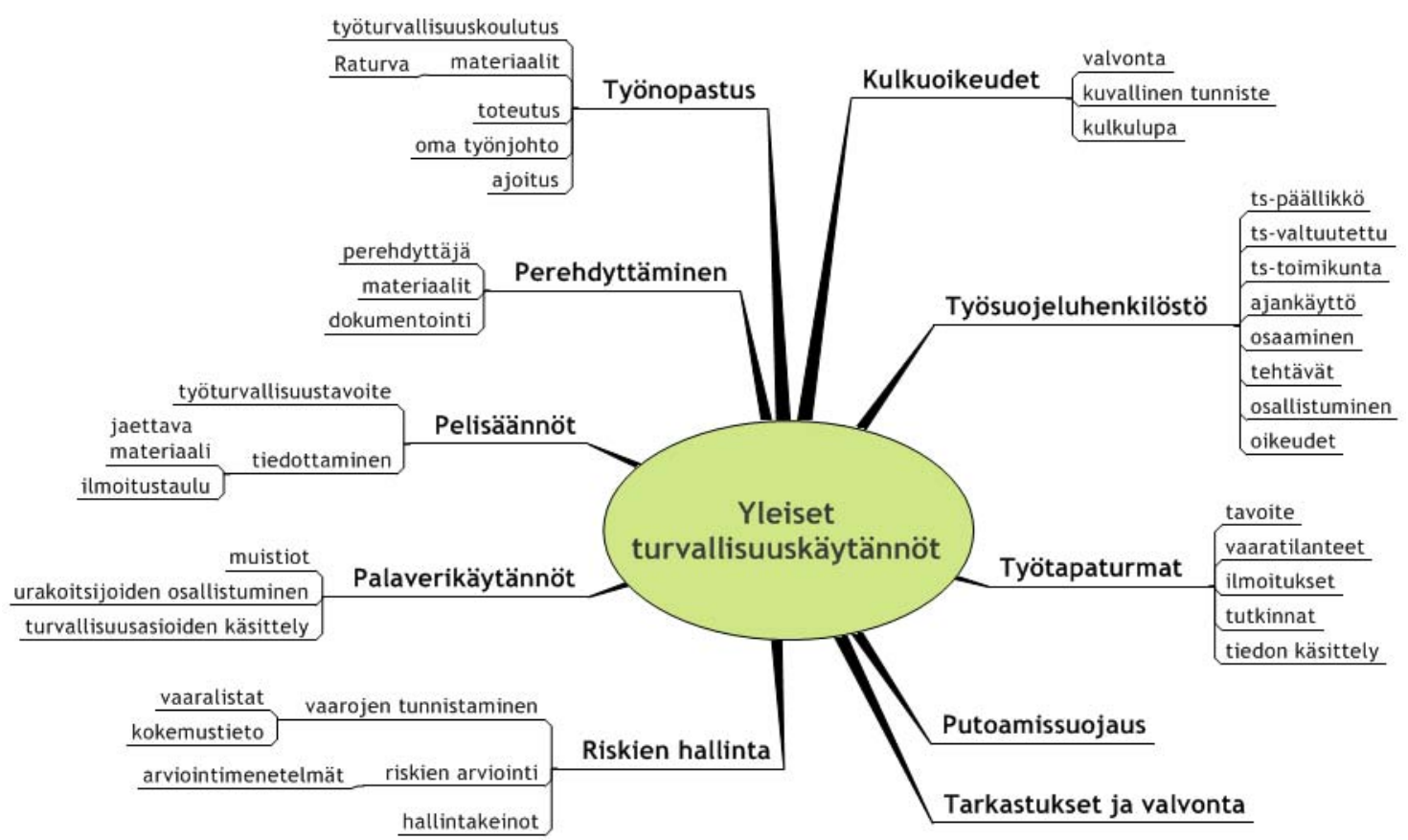

Kuva 1. Käsitekartta rakennustyömaan yleisistä turvallisuuskäytännöistä ja turvallisuussuunnittelun osa-alueista (Mäkelä 2006).

Työmaan päätoteuttaja ja tilaaja määrittelevät työmaan pelisäännöt. Pelisääntöjen taustalla ovat työmaalle asetetut työturvallisuustavoitteet. Pelisääntöjen tulee olla selkeitä toimintatapoja, jotka kerrotaan kaikille työmaalla työskenteleville ja joita koko työmaa sitoutuu noudattamaan. Pelisääntöjen noudattamista tulee koko työmaahenkilöstön valvoa jatkuvasti.

\section{Riskien hallinta}

Riskien hallinnan kannalta on ensiarvoisen tärkeää tunnistaa mahdolliset vaaratekijät ja -tilanteet etukäteen, koska tunnistamatonta riskiä ei pysty hallitsemaan. Turvallisuusriskien tunnistuksessa tulee tunnistaa ja arvioida sekä yleisiä rakennustyön turvallisuusriskejä että kohdekohtaisia erityisriskejä. Rakennustyöhön liittyy ns. yleisiä rakennustyön vaaroja, kuten naulaan astuminen sekä rakennushankekohtaisia erityisiä vaaratekijöitä, kuten purkutyöt (Mäkelä 2006).

Tutkimusten mukaan on erittäin vaikea tunnistaa riskit kattavasti. Riskien tunnistusta rajoittavia tekijöitä liittyy niin osaamiseen, tietoon, prosessiin kuin menetelmiin. Näitä ovat mm. yhteisen tiedon puuttuminen, resurssien vähäisyys erityisesti pienissä projekteissa, riippuvuus ns. hiljaisesta (piilevästä) tiedosta, vaarojen tunnistamisen ja riskien arvioinnin subjektiivisuus sekä järjestelmällisten menettelyjen puuttuminen (Carter ja Smith, 2006).

Riskien arvioinnissa ja tunnistuksessa apuna voidaan käyttää erilaisia menetelmiä, kuten tarkistuslistoja ja arvioinnissa puolestaan erilaisia analyysimenetelmiä ja -lomakkeita tai räätälöityjä arviointimenetelmiä. Järjestelmällisellä riskien arvioinnilla analysoidaan koko rakentamisprojekti, kaikki työvaiheet, tontti, lähiympäristö jne. Arviointia tukee kaikki käytettävissä oleva tieto kyseisestä kohteesta ja projektista sekä kertyneet kokemukset muista arvioinneista, tapaturmista ja vaaratilanteista. 


\section{Turvallisuussäännösten tuntemus}

Valtioneuvoston asetus rakennustyön turvallisuudesta (VnA 2009) oli suunnittelijoille pääosin tuttu. 30 \% suunnittelijoista kertoi tuntevansa sen hyvin ja jalkauttavansa sisältövaatimusta suunnittelukohteisiinsa. Yleensä jalkauttaminen tapahtui tarjouspyyntöasiakirjojen, työturvallisuusliitteen avulla tai viimeistään aloituskokouksessa. Työmaan edetessä turvallisuusseikkojen valvonta ja toteutus jäi yksinomaa rakennuttajan l. viljelijän vastuulle. Rakennuttajien tietoisuus lain velvoitteista on suunnittelijoiden käsityksen mukaan olematonta. Niinpä työmaan turvallisuussuunnitelmia ei juurikaan laadita.

Turvallisuuskoordinaattori nimetään noin 50\%:ssa suunnittelijoiden hoitamia työmaita, ja silloinkin se yleensä on isäntä eli rakennuttaja itse. Työmaan aloituskokous on pidetty noin 80 \%:sti työmailla. Yleisesti kokoukset on viety läpi paikallisten rakennusvalvontaviranomaisten käytäntöjen mukaisesti. Turvallisuuskysymykset niissä on sivuutettu muutamalla maininnalla, joissa rakennuttajia muistutetaan velvoitteistaan. Työmaakokouksia on suunnittelijoiden kokemusten mukaan pidetty säännöllisesti jopa 70\%:ssa rakennuskohteista. Loput 30\% on pidetty tarvittaessa tai ne ovat rajoittuneet vain aloituskokoukseen, jos edes siihenkään.

Suunnittelijat tunsivat Työturvallisuuslakia (Työturvallisuuslaki 2003) jossain määrin: 40\% kertoi tuntevansa sen kohtuullisen hyvin, ja 60\% vain jonkin verran tai heikosti. Suunnittelijoiden arvion mukaan rakennuttajien tieto laista on lähes olematon. Lain tilaajan selvitysvelvollisuudesta ja vastuusta ulkopuolista työvoimaa käytettäessä (Laki 1233/2006) suunnittelijat tunsivat mielestään hyvin 45\%:ssa vastauksia. Loput 65\% tunsi heikosti tai ei lainkaan. Rakennuttajat tuntevat lain vaatimukset vielä heikommin. Tilaajan selvitysvelvollisuus on yleensä otettu esiin aloituskokouksissa ja sen katsottiin toteutuneen noin 50\%:ssa tapauksista.

\section{Viljelijöiden parannusehdotuksia}

Rakennushankkeen toteuttaneet viljelijät esittivät kokemuksensa perusteella seuraavia ehdotuksia työturvallisuuden parantamiseksi rakennustyömailla:

- "henkilönostin olisi voitu vuokrata räystäslaudoituksia varten, mutta ei vuokrattu, tehtiin alumiinitelineiltä"

- "jos nyt alkaisi uuden projektin, niin urakoitsijoita velvoitettaisiin siivomaan jokaisen päivän päätteeksi, sekalainen lattia on kompastumisriski ja paloriski kasvaa”

- "ne turvaliivit olisivat olleet asialliset kattotöissä"

- "kattomuovin asennuksessa olisi voitu käyttää valjaita"

- "putoamista vastaan olisi voitu valjaita käyttää, onneksi vahinkoa ei tapahtunut”

• "sitä kypärän käyttöä olisi voinut vaatia ponnekkaammin, mutta kun timpurit eivät helteellä halunneet käyttää, harjoittelijapoikaa piti patistaa suojainten käyttöön”

\section{Johtopäätökset}

Tilaaja yhdessä päätoteuttajan kanssa pystyy parhaiten vaikuttamaan rakennusprojektin turvallisuustoiminnan tasoon ja asettamaan toiminnalle turvallisuustavoitteet, joihin myös käytännön toimenpitein pyritään. Tavoitteena pitää olla "nolla tapaturmaa” ja toimintatapana "turvallisuus on aina ensin". Erityisesti viljelijä-rakennuttajan tietämystä hänen lakisääteisistä työturvallisuusvelvoitteistaan ja niiden käytännön hoitamisesta rakennushankkeessa on parannettava.

Turvallisuuden kannalta hyviä toimintatapoja ja vaatimuksia:

- $\quad$ suunnittelussa on mukana turvallisuus/toteutettavuusnäkökulma

- $\quad$ samat turvallisuusvaatimukset koskevat kaikkia

- $\quad$ kaikilta projektin työntekijöiltä vaaditaan turvallisuuskoulutukseen osallistumista

- $\quad$ yleiset turvallisuusohjeet sisältyvät urakkasopimuksiin

- $\quad$ kaikista työntekijöiden onnettomuuksista vaaditaan välitöntä raportointia

- turvallisuus sisällytetään aina palavereiden asialistalle, turvallisuuskeskustelut käydään jokaisen palaverin alussa

- $\quad$ työmaan jokainen työntekijä perehdytetään ennen töiden aloittamista 


\section{Kirjallisuus}

Carter G. \& Smith S. 2006. Safety Hazard Identification on Construction Projects. In Journal of construction engineering and management. February 2006. ASCE. p. 197-205

Laki 1233/2006. Laki tilaajan selvitysvelvollisuudesta ja vastuusta ulkopuolista työvoimaa käytettäessä. Viitattu 2.12.2011. http://www.finlex.fi/fi/laki/alkup/2006/20061233

Latvala, T. \& Pyykkönen, P. 2009. Teknotila-hankkeen tuloksia. 20.08.2009. Henkilökohtainen tiedonanto.

MMM 2009. Maa- ja metsätalousministeriö. Maaseudun kehittäminen / Maaseudun rakentaminen / Maatilarakentaminen. Viitattu 30.11.2011.

http://www.mmm.fi/fi/index/etusivu/maaseudun_kehittaminen/maaseuturakentaminen/maatilarakentaminen.html

Mäkelä, T. 2006. Pientalojen aluerakentamisen työturvallisuus. VTT tutkimusraportti VTT-R-07902-06.

Oinonen, K. \& Aaltonen, M. 2007. Työterveys ja työturvallisuus tuottavuustekijänä. Työtapa-turmien aiheuttamat kustannukset. Työturvallisuuden merkitys työpaikkojen tuottavuuteen -projektin tutkimusosio 2:n loppuraportti Työsuojelurahastolle.

Tilastokeskus 2009. Tilastokeskus. Verkkopalvelut /Suomi lukuina / rakentaminen. Viitattu 30.11.2011. http://www.stat.fi/tup/suoluk/suoluk_rakentaminen.html

Työturvallisuuslaki 2003. Työturvallisuuslaki 738/2002. Viitattu 30.11.2011.

http://www.finlex.fi/fi/laki/smur/2002

VnA 2009. Valtioneuvoston asetus rakennustyön turvallisuudesta. Viitattu 30.11.2011.

http://www.finlex.fi/fi/laki/smur/2009/ 